\title{
Resultan Sistem Pemilu dan Sistem Pemerintahan terhadap Pelaksanaan Demokrasi di Indonesia
}

\author{
Anajeng Esri Edhi Mahanani
}

Universitas Pembangunan Nasional “Veteran” Jawa Timur; email : anajengmahanani.ih@upnjatim.ac.id

\begin{abstract}
Problems related to the resultant electoral system and the government system are the focus of the discussion in this study. Types of electoral systems, as well as types of governmental systems are discussed to be able to be a study of the use of electoral systems and government systems. The purpose of discussing this problem is to analyze the electoral system and the government system that are compatible with the implementation of democracy in Indonesia. This research is discussed through normative analysis, and through qualitative methods. The results of the qualitative normative analysis can be seen as follows: First, the results of the analysis show that there is a resultant between the electoral system towards the implementation of democracy in Indonesia as seen from the theory of the people's unity and the representative system. The consultant becomes strong if the general election system used is a purely open proportional electoral system, namely the voter as the supreme sovereignty constitution, can know with certainty who the candidate is and will help determine who is the people's representative. Second, there is a result between the government system and the implementation of democracy, the theory of popular sovereignty and the system of representation. Parliamentary and presidential government systems have their own weak points and strengths. However, the presidential system applied in democratic countries in Indonesia is better, because it tends to be more stable in its accountability. Placing the highest sovereignty as the only party that accepts the responsibility of those who have been elected to the executive and parliamentary institutions. The concept developed is a system of political representation, not as a system of partisan representation .
\end{abstract}

Keywords: Resultan, District System, Proporsional System, Presidensiil, Parlementer

\section{Pendahuluan}

Membahas terkait pemilu (pemilihan umum) selalu memiliki resultan dengan demokrasi. Demokrasi dalam definisi harfiah memiliki arti pemerintahan dari rakyat (Arend Lijhpart, 1984 : 1), merupakan pemahaman paling mendasar dan paling mainstream digunakan. Demokrasi yang acapkali dihubungkan dengan kedaulatan rakyat yang kemudian diterapkan di Indonesia atas dasar Pasal 1 ayat (2) Undang-Undang Dasar Negara Republik Indonesia, yang mengatur "Kedaulatan berada di tangan rakyat dan dilaksanakan menurut Undang-Undang Dasar" mencerminkan bahwa penyelenggaraan pemerintahan, berbangsa dan bernegara letak dasar nya adalah pada rakyat. Selanjutnya, Undang-Undang Dasar Negara Republik Indonesia juga semakin menegaskan adanya sarana rakyat ikut serta dalam penyelenggaraan pemerintahan, berbangsa dan bernegara, yakni melalui pemilihan umum yang diatur dalam BAB VIIB, Pasal 22 E Undang-Undang Dasar Negara Republik Indonesia Tahun 1945. Pemilihan umum merupakan 
Jurnal Yustika

Vol. 22 No. 02, Des 2019

Halaman I 75

Resultan Sistem

Pemilu dan Sistem

Pemerintahan

terhadap

Pelaksanaan

Demokrasi di

Indonesia

Anajeng Estri Edhi

Mahanani

sarana paling mudah memastikan keikutsertaan masyarakat selaku konstituen untuk ikut serta menentukan siapa yang berhak menduduki pemerintahan maupun lembaga legislative. Demokrasi yang diselenggarakan melalui pemilihan umum, dalam hal ini merupakan implikasi dari tidak dimungkinkannya penyelenggaraan demokrasi langsung dalam artian konvensional.

Secara konvensional, sistem demokrasi langsung menghendaki rakyat secara langsung mengemukakan kehendaknya dalam forum yang dihadiri oleh seluruh rakyat, yang dimungkinkan dijalankan pada negara berpenduduk sedikit dan berwilayah kecil. Sistem ini pernah berlaku di Negara Athena pada zaman Yunani Kuno, yakni pada abad IV SM (Dwi Sulisworo, dkk., 2012 :13). Sebaliknya, demokrasi tidak langsung kemudian diterapkan melalui demorkasi perwakilan, secara representative maupun referendum. Pemilihan umum merupakan salah satu bentuk perwujudannya untuk mencapai tujuan demokrasi namun secara tidak langsung. Hal ini sebagai akibat dari tidak dimungkinkannya lagi pada era modern diselenggarakan demokrasi secara langsung, melihat kompleksitas kebutuhan masyarakat, majemuknya masyarakat, dan luas wilayah Negara yang tidak hanya sesempit dan sesederhana sebagaimana di era Yunani Kuno.

Tepat kemudian, apabila pembahasan demokrasi perwakilan diresultankan dengan pembahasan pemilihan umum yang merupakan sarana penyelenggaraan demokrasi di masa modern. Resultan atau hubungan antara pemilihan umum dengan demokrasi tidak hanya berhenti pada pembenaran hakikat sarana demokrasi di era modern saja, namun pembahasan diarahkan pada jenis tipe pemilihan umum dalam negara demokrasi Indonesia yang nantinya juga akan dihubungkan dengan penerapan sistem pemerintahan di Indonesia.

Indonesia memilih menerapkan sistem pemerintahan presidensiil, mengingat bahwa salah satu tujuan reformasi adalah memurnikan sistem pemerintahan yang menempatkan kepala negara dan kepala pemerintahan pada tampuk kekuasaan presiden. Sistem presidensiil mendorong adanya kekuatan presiden yang tidak mudah digoyahkan oleh parlemen, begitu juga oleh koalisi parlemen. Dalam rangka memperkuat sistem presidensiil, maka sistem pemilu yang memperkecil kemungkinan adanya kekuatan partai politik atau koalisi partai politik di tubuh parlemen, menjadi suatu pilihan yang tepat.

Sistem pemerintahan presidensiil juga mempengaruhi penyelenggaraan demokrasi di Indonesia yang lebih menempatkan rakyat sebagai konstituen pemilih dan penerima langsung pertanggungjawaban presiden, bukan melalui partai politik atau koalisi partai politik yang duduk di parlemen. Berdasarkan pembahasan korelasi hubungan antara sistem pemilu, sistem pemerintahan dengan demokrasi, nyatanya memiliki resultan satu sama lain. Ketepatan pelaksanaan sistem pemilu, sistem pemerintahan dalam negara demokrasi Indonesia menjadi tujuan untuk menciptakan penyelenggaraan pemerintahan, berbangsa dan bernegara sesuai dengan tujuan diselenggarakannya negara demokrasi representative.

Artikel ini akan membahas terkait resultan sistem pemilu terhadap pelaksaanan demokrasi di Indonesia, serta resultan sistem pemerintahan terhadap pelaksanaan demokrasi di Indonesia. Keduanya akan dianalisis lebih mendalam melalui pendekatan teori kedaulatan rakyat dan sistem perwakilan.

\section{Pembahasan}

Pada bab sebelumnya telah dibahas secara singkat resultan sistem pemilu, sistem pemerintahan terhadap pelaksanaan demokrasi di Indonesia. Bahasan tersebut perlu kemudian 
dianalisis secara lebih mendalam dan komprehensif melihat juga dari teori kedaulatan rakyat dan sistem perwakilan. Sehingga analisis dapat dipergunakan untuk menentukan tipe pelaksanaan sistem pemilu yang seperti apa yang dapat mendukung penyelenggaraan sistem pemerintahan dan pelaksanaan demokrasi di Indonesia.

\subsection{Resultan Sistem Pemilu terhadap Pelaksanaan Demokrasi di Indonesia ditinjau dari Teori Kedaulatan Rakyat dan Sistem Perwakilan}

Berbicara tentang sistem pemilihan umum, terdapat sistem pemilihan mekanis dan organis, yang keduanya dilihat dai kedudukan individu. Perbedaan hak suara individu dilihat dari apabila sistem mekanis melihat bahwa rakyat terdiri atas individu-individu di mana hak suara berada pada masing-masing individu. Berbeda dengan sistem mekanis, sistem organis menempatkan rakyat sebagai sejumlah kelompok individu atau dengan kata lain, rakyat kemudian dibagi dalam organ kelompok-kelompok individu. Kelompok dibentuk berdasarkan geneologis, lapisan social, organisasi kelembagaan, dan sebagainya. Hal ini kemudian mendorong hak suara pada sistem organis terletak pada kelompok (Moh. Kusnardi, Harmaily Ibrahim, 1981 : 333-335).

Menilik pada kedua sistem pemilihan tersebut di atas, maka melihat bahwa tiap-tiap Warga Negara Indonesia memiliki hak suara dan hak sipil politik, sehingga sistem pemilihan yang kemudian dianut adalah sistem pemilihan mekanis. Hak suara dinilai sebagai hak masingmasing individu yang dihitung secara perorangan penuh. Dapat disimpulkan, adaya suara kelompok tidak cukup untuk mewakili kehendak konstituen masing-masing, maka sistem pemilihan organis tidak dimungkinkan.

Praktek pemilihan mekanis nyatanya diakomodir dalam pengaturan konstitusi Pasal 1 ayat (2) Undang-Undang Dasar Negara Republik Indonesia Tahun 1945 pasca amandeman yang berbunyi "kedaulatan berada di tangan rakyat, dan dilaksanakan menurut Undang-Undang Dasar. Hal mana menampik keberlakuan sistem organis yang secara implisit terlihat sempat diakomodir dalam Pasal 1 ayat (2) Undang-Undang Dasar 1945 sebelum amandemen, yang berbunyi, "kedaulatan adalah di tangan rakyat dan dilaksanakan sepenuhnya oleh Majelis Permusyawaratan Rakyat". Bunyi Pasal 1 ayat (2) Undang-Undang Dasar 1945 sebelum amandemen tersebut menunjukkan adanya perwakilan kelompok yang nantinya menjalankan kedaulatan rakyat, yang saat itu diimpelemntasikan dalam penyelenggaraan pemerintahan bernegara, khususnya dalam memilih presiden ditentukan oleh Majelis Permusyawaratan Rakyat. Hal yang tidak sesuai dengan konsep satu orang satu suara tanpa diwakilkan.

Selanjutnya, pembahasan terfokus pada sistem pemilihan mekanis yang memiliki dua cara pelaksanaan, yakni sistem perwakilan distrik atau mayoritas atau single member constituencies, serta sistem perwakilan proporsional. Baik sistem perwakilan proporsional maupun sistem perwakilan distrik memiliki perbedaan model. Untuk perwakilan proporsional, mendesain perwakilan berimbang antara jumlah wakil dengan jumlah perolehan secara nasional, sehingga apabila disimpulkan maka dapat diketahui terdapat korelasi antara proporsi jumlah penduduk dan wakil yang duduk di lembaga perwakilan. Proporsional di sini juga disesuaikan antara 
Jurnal Yustika

Vol. 22 No. 02, Des 2019

Halaman | 77

Resultan Sistem

Pemilu dan Sistem Pemerintahan terhadap Pelaksanaan Demokrasi di Indonesia

Anajeng Estri Edhi Mahanani prosentase kursi di badan perwakilan rakyat dengan prosentase jumlah suara yang diperoleh oleh partai politik secara keseluruhan, bukan didasarkan pada siapa yang memperoleh suara terbanyak.

Berbeda dengan model sebagaimana di atas, sistem pemilihan distrik merupakan sistem pemilihan mayoritas yang menentukan wakil terpilih berdasarkan siapa calon yang mendapatkan jumlah suara terbanyak, namun konsep perwakilan distrik juga kuat, yakni membagi wakil berdasarkan distrik pemilihan. Melihat dua model sistem pemilihan tersebut, Duverger (Sekretariat Jenderal Bawaslu RI, 2015:12-13) merumuskan, bahwa model sistem pemilihan, masing-masing menimbulkan efek psikologis. Efek psikologis yang dimaksud adalah pengambilan strategi pemilih. Dalam rumusan ini, Duverger menerangkan, bahwa pada sistem distrik, pemilih akan cenderung memilih kandidat atau calon yang baik kualitas maupun kuantitasnya berpeluang besar untuk menang. Sebaliknya, pada model sistem pemilihan proporsional, pemilih akan tetap memilih partai politik.

Mohammad Syaiful Aris dalam penelitiannya (2018:311) menegaskan bahwa:

"Penerapan sistem pemilu mayoritarian (distrik) dimana "the winner take alls" nampaknya perlu dipertimbangkan sebagai alternatif atas penerapan sistem pemilu proporsional yang selama ini digunakan di Indonesia. Penggunaan sistem distrik diyakini mampu mendorong secara alamiah penyederhanaan partai politik serta peningkatan akuntabilitas calon terpilih. Akan tetapi penerapan sistem mayoritarian/plurality (distrik) dikhawatirkan menyebabkan ketidaknyamanan karena Indonesia adalah negara yang sangat heterogen dan perlu memperhatikan kelompok minoritas."

Dari analisis sebelumnya, dan hasi penelitian sebelumnya di atas, penulis juga menganalisis lebih lanjut, bahwasannya terdapat kelebihan dan kekurangan baik sistem proporsional maupun distrik apabila diterapkan dalam negara demokrasi Indonesia. Melalui sistem proporsional, menguatkan posisi partai politik pada negara demokrasi adalah hal yang penting. Sistem proporsional yang menitik beratkan pada kekuatan partai politik tidak hanya calon yang ada di dalamnya, memberikan ruang kepada partai politik yang merupakan infrastruktur demokrasi berlomba untuk membangun partai politik dengan baik. Kekurangan nya adalah melihat dari potensi semakin banyaknya pratia politik yang menjamur, sehingga multi partai menjadi kuat pada negara demokrasi.

Kemudian membahas kelebihan dan kelemahan sistem distrik. Sebagai negara dengan kebutuhan pluralitasnya yang plural, komoleks, heterogen, maka pemilihan yang diselenggarakan untuk seluruh lembaga legislative dengan sistem pembagian wilayah distrik murni, maka akan memperkuat adanya mayoritas berkuasa dan mengesampingkan kebutuhan minoritas. Namun, sistem distrik justru mendorong sedikitnya partai politik yang lahir. Tepat ketika tujuan demokrasi kita bukan hanya semata membangun banyak partai dalam negara, namun hal ini secara tidak langsung mendorong kepercayaan public terhadap individu per wilayah bukan pada partai politiknya. 
Menjadi penting kemudian menerapkan sistem pemilihan umum yang merupkan kombinasi di antara kedua sistem pemilihan di atas, yakni pemilihan proporsional dan pemilihan distrik. Indonesia, pada pemilihan umum tahun 1955, menganut sistem proporsional. Melalui sistem proporsional, alokasi jumlah kursi di lembaga perwakilan didasarkan pada perolehan suara proporsional dari masing-masing partai. Variasi proporsional yang diterapkan pada Thaun 1955 ini menggunakan hare system. Yakni pemilih diberikan kesempatan untuk memilih pilihan yang pertama, kedua dan seterusnya, dari distrik pemilihan yang bersangkutan. Variasi sistem ini menentukan bahwa apabila jumlah utama suara pertama sudah terpenuhi dan bersisa, maka kelebihan suara dapat dipindahkan kepada calon berikutnya. Berbeda dengan varian list system yang menegaskan bahwa pemilih dapat diminta memilih di antara daftar calon yang berisi sebanyak mungkin nama-nama wakil rakyat yang akan dipilih dalam pemilihan umum.

Sistem yang kemudian tetap dipertahankan adalah sistem proporsional yang terbuka namun terbatas, sebagaimana hal ini dianut oleh Undang-Undang Nomor 10 Tahun 2008. Undang-Undang ini kemudian mengatur sistem pemilihan yang proporsional terbuka terbatas, yakni apabila proporsional tertutup mengarahkan pemilih ibarat memilih kucing dalam karung, namun proporsional terbuka terbatas mendorong pemilih untuk tetap mengetahui nama-nama yang diutamakan oleh partai politik tersebut mrnjadi calon utama yang masuk sebagai pilihan yakni dengan menentukan nomor urut dan beresultan terhadap hasil pemilihan umum. Denga kata lain, sistem pemilihan proporsional terbuka terbatas ini hanya memfokuskan pada pada nomor urut.

Sistem pemilihan proporsional terbuka terbatas ini ternyata masih belum menjawab kelemahan proporsional. Pemilih sebagai pemegang kedaulatan rakyat semestinya tidak dibatasi dengan adanya nomor urut. Partai politik bukanlah penentu dari hitungan suara dan kualitas pemilihan. Dengan kata lain, kualitas pemilihan tidak dapat dibatasi dengan atruan nomor urut partai politik. Sekali lagi, konse kedaulatan rakyat Pasal 1 ayat (2) Undang-Undang Dasar Negara Republik Indonesia Tahun 1945 menempatkan rakyat sebagai penguasa atau pemegang kedaulatan tertinggi sampai dengan menentukan sendiri wakil rakyat yang dipilihnya, bukan ditentukan oleh partai politik.

Partai politik semestinya merupakan salah satu dari bentuk pelembagaan sebagai wujud ekspresi ide-ide, pikiran-pikiran, pandangan dan keyakinan bebas dalam masyarakat (Jimly Asshiddiqie, 2005 : 53). Maka menjadi tidak tepat apabila justru partai politiklah yang menerapkan praktek pembatasan keyakinan bebas masyarakat dalam memilih.

Lalu bagaimana dnegan sistem pemilihan proporsional terbuka murni? Sistem pemilihan terbuka murni, berbeda dengan sistem pemilihan terbuka terbatas yang mana partai memiliki kekuasaan dalam menentukan nomor urut calon akil rakyat dan berpengaruh terhadap siapa 
Jurnal Yustika

Vol. 22 No. 02, Des 2019

Halaman I 79

Resultan Sistem

Pemilu dan Sistem Pemerintahan terhadap Pelaksanaan Demokrasi di Indonesia

Anajeng Estri Edhi Mahanani

yang nantinya menang menduduki kursi wakil rakyat. Sistem pemilihan terbuka murni, mengadopsi sistem distrik dengan kosnep mayoritas, namun tidak berdasarkan kategori pembagian wilayah murni. Sistem perwakilan terbuka murni mendorong masyarakat untuk memilih calon secara bebas, tanpa dibatasi pengaturan nomor urut oleh partai politik. Harapan dengan adanya Putusan Mahkamah Konstitusi Nomor 24/PUU-VI/2008 yang mengubah dari sistem pemilu proporsional tertutup menjadi terbuka murni tidak hanya terbatas menunjukkan adanya semangat yang kuat untuk menegaskan prinsip kedaulatan rakyat, bukan kedaulatan partai. Calon wakil rakyat dalam hal ini berlomba untuk memperoleh suara konstituen bukan partai politik, sehingga partai politik tidak serta merta berkuasa dan menguasai calon-calon legislatifnya.

Ideal atau tidaknya sistem pemilihan proporsional terbuka murni kemudian dapat ditentukan atau didasarkan pada kemandirian dan kedewasaan dari partai politik, serta pemilih. Partai Politik dan pemilih yang cerdas tidak menekankan pada tokoh yang dapat "menjual" dan berjuang meraup suara dengan cara yang tidak dibenarkan, misal politik uang atau kekuasaan. Konsep proporsional terbuka murni ini justru mendorong konstituen untuk membangun perwakilan deliberative, yang responsive dan betul-betul melihat dari visi, misi, kinerja sampai dengan calon perorangan, tidak hanya partai politik.

Pemilihan umum yang menempatkan suara rakyat sebagai pemegang hak sipil politik, termasuk penentu dalam suara pemilihan umum, merupakan konsep yang selaras dengan prinsip demokrasi. Dijelaskan selanjutnya oleh Arend Lijhpard, bahwa sebuah negara yang menyatakan dirinya sebagai negara demokrasi, adalah negara yang memenuhi unsur-unsur sebagai berikut: (Bagir Manan, 1996 : 58)

1. Ada kebebasan untuk membentuk dan menjadi anggota perkumpulan;

2. Ada kebebasan menyatakan pendapat;

3. Ada hak untuk memberikan suara dalam pemungutan suara;

4. Ada kesempatan untuk dipilih atau menduduki berbagai jabatan pemerintah atau negara;

5. Ada hak bagi para aktivis politik berkampanye untuk memperoleh dukungan atau suara;

6. Terdapat berbagai sumber informasi;

7. Ada pemilihan yang bebas dan jujur;

8. Semua lembaga yang bertugas merumuskan kebijakan pemerintah, harus bergantung kepada keinginan rakyat.

Sistem pemilihan umum yang membuka ruang bagi konstituen untuk mengenal wakilnya, sehingga wakil rakyat yang terpilih memiliki hubungan tanggungjawab psikologis dengan konstituen pemilihnya, merupakan tujuan demokrasi yang deliberative.

Hubungan wakil yang erat dengan konstituennya akan menempatkan konstituen di posisi penting, sehingga aspirasi konstituen menjadi hal yang harus diperjuangkan wakil (Idrus 
Affandi, 2006 : 2). Konsep sismtem pemilihan proporsional terbuka murni diharapkan dapat mewujudkan hubungan wakil dan terwakil dengan tepat dan sesuai. Wakil mengetahui tanggungjawab nya atas konstituen, dan konstituen benar-benar mengetahui dan menentukan siapa wakil yang dipilihnya untuk diberikan tanggungjawab pelaksanaan kedaulatan rakyat berdasarkan undang-undang dasar.

Sistem pemilihan umum proporsional terbuka murni, membatasi lahirnya tipe perwakilan yang menempatkan wakil rakyat sebagai partisan. Wakil rakyat sebagai partisan (Miriam Budiardjo dan Ibrahim Ambong, 1993), menurut tipe ini wakil bertindak sesuai dengan program dari partai atau organisasinya. Wakil akan lepas hubungannya dengan pemilih (pihak yang diwakili) begitu proses pemilihan selesai. Wakil hanya terikat kepada partai atau organisasi yang mencalonkannya.

\subsection{Resultan Sistem Pemerintahan terhadap Pelaksanaan Demokrasi di Indonesia ditinjau dari Teori Kedaulatan Rakyat dan Sistem Perwakilan}

Berbicara tentang sistem pemerintahan, maka pembahasan mengarah pada jenis sistem pemerintahan yakni hubungan antara eksekutif dan parlemen yang dibagi menjadi dua jenis, yakni sistem pemerintahan yang paling dikenal, yakni sistem pemerintahan presidensiil dan sistem pemerintahan parlementer. Selain dua sistem pemerintahan tersebut, adapula jenis sistem pemerintahan yang lain yakni sistem pemerintahan quasi maupun referendum. Namun yang akan menjadi pembahasan lengkap di sini adalah sistem pemerintahan parlementer dan sistem pemerintahan presidensiil yang keduanya pernah dipraktekkan dalam pemerintahan di Indonesia.

Sistem pemerintahan parlementer digunakan legislatif untuk mengawasi eksekutif , sehingga dalam sistem ini, kekuasaan parlemen lebih besar daripada eksekutif. Hasil dari pengawasan ini, Dewan Menteri (kabinet) bertanggungjawab kepada parlemen (Syafiie, 2011). Selanjutnya, ditegaskan bahwa pertanggungjawaban ini membuat adanya mosi tidak percaya apabila adanya ketidakpercayaan terhadap kinerja kabinet yang dipimpin oleh perdana menteri.

Sistem parlementer memiliki kriteria adanya hubungan antara legislative, eksekutif, yang antara keduanya saling mempengaruhi. Sistem pemerintahan parlementer yang dapat pula disebut sebagai the parliamentary types of government, memiliki ciri-ciri sebagai berikut: (Mariana, Paskalina \& Yuningsih, 2007 : 10)

(1) Kepala negara hanya mempunyai kekuasaan nominal. Hal ini berarti bahwa kepala negara hanya merupakan lambing / symbol yang hanya mempunyai tugas-tugas yang bersifat formal, sehingga pengaruh politiknya terhadap kehidupan negara sangatlah kecil.

(2) Pemegang kekuasaan eksekutif yang sebenarnya / nyata adalah perdana menteri bersama-sama kabinetnya yang dibentuk melalui lembaga legislative/parlemen; 
Jurnal Yustika

Vol. 22 No. 02, Des 2019

Halaman | 81

Resultan Sistem Pemilu dan Sistem Pemerintahan terhadap Pelaksanaan Demokrasi di Indonesia Anajeng Estri Edhi Mahanani dengan demikian kabinet sebagai pemegang kekuasaan eksekutif riil harus bertanggungjawab kepada badan legislative/parlemen dan ahrus meletakkan jabatannya bila parlemen tidak mendukungnya.

(3) Badan legislative dipilih untuk bermacam-macam periode yang saat pemilihannya ditetapkan oleh kepala negara atas saran dari perdana menteri.

Point utama sistem pemerintahan parlementer sebenarnya terletak pada dapat saling menjatuhkannya antara eksekutif dengan parlemen. Hal ini sesuai dengan pendapat dari Mr. Achmad Sanusi, yang menjelasan ciri-ciri sistem parlementer sebagai berikut: (Mariana, Paskalina \& Yuningsih, $2007: 12$ )

(1) Kedudukan kepala negara tidak dapat diganggu gugat;

(2) Kabinet yang dipimpin oleh perdana menteri bertanggungjawab kepada parlemen;

(3) Susunan personalia dan program cabinet didasarkan atas suara terbanyak di parlemen;

(4) Masa jabatan kabinet tidak ditentukan dengan tetap atau pasti berapa lamanya;

(5) Kabinet dapat dijatuhkan pada setiap waktu oleh parlemen, sebaliknya parlemen dapat dijatuhkan oleh pemerintah.

Bisa pula point ini menunjukkan adanya ketidak stabilan sistem parlementer, meskipun tidak dapat dipukul rata demikian. Pada beberapa kasus justru sistem pemerintahan parlementer yang membuka ruang saling menjatuhkan dapat mendorong dibentuknya kekuatan koalisi baik di tubuh parlemen dengan tubuh eksekutif.

Dikaitkan dengan teori kedaulatan rakyat dan perwakilan rakyat, maka sistem pemerintahan parlementer di lain sisi mewujudkan demokrasi perwakilan yang kuat, karena wakil rakyatlah yang mewakili konstituen untuk mengawasi kinerja pemerintah. Hal ini sesuai dengan konsep parliamentary mandate (I Gde Pantja Astawa, 2000 : 96-97)), yang salah satunya menekankan kewajiban kepada wakil rakyat untuk berpartisipasi dalam pembahasan dan pengawasan politik dan kebijaksanaan nasional.

Pembahasan sistem pemerintahan berikutnya adalah sistem pemerintahan presidensiil. Sistem pemerintahan presidensiil, menurut Sarundajang (2012 : 35), merupakan sistem pemerintahan yang menempatkan presiden sebagai kepala negara sekaligus sebagai kepala eksekutif. Presiden bukan dipilih oleh Parlemen, justru yang diterapkan adalah pemilihan secara langsung yang diselenggarakan bersama untuk memilih Presiden dan Parlemen. Sistem ini kemudian juga melahirkan konsep tidak adanya pertangungjawaban Presiden dan Kabinet kepada parlemen. Sehingga terhadap keduanya tidak dapat saling menjatuhkan.

Selain ciri yang utama dari sistem presidensiil di atas, S.L Witman dan JJ Wuest juga menyampaikan terdapat empat ciri lainnya dan syarat sistem presidensiil, yakni : (Syafiee, 2011 :90)

(1) It is based upon the separation of power principle 
(2) The executive has no power to dissolvethe legislature nor must he resign when he loses the support of the majority of its membership

(3) There is no mutual responsibility between the president and his cabinet, thelatter is wholly responsible to the chief executive

(4) The executive is chosen by the electorate

Berdasarkan ciri tersebut terkait dengan teori kedaulatan rakyat dan sistem perwakilan, memiliki dua sudut pandang. Sudut pandang yang pertama, dengan tidak adanya pertanggungjawaban kepada parlemen, maka yang terjadi adalah presiden bisa saja memiliki kekuasaan yang besar, sehingga yang muncul adalah setiap kebijakan pemerintahan yang diambil berdasarkan bargaining position, sehingga yang terlihat adalah perwakialn representatif - elitis dan bukan partisipatif - populis.

Sudut pandang yang kedua, secara positif, presidensiil merupakan sistem pemerintah yang dapat mendukung teori kedaulatan dan perwakilan. Dapat dilihat bahwa presidensiil meletakkan pertanggungjawaban langsung kepada rakyat, tidak melalui lembaga perwakilan rakyat atau parlemen. Terlihat bahwa konstituen di tempatkan sebagai pemegang kedaulatan tertinggi. Posisi parlemen hanya sebagai check and balances, bukan sebagai penentu bertahan atau tidaknya suatu kabinet. Konsep perwakilan yang dibangun dalam sistem pemerintahan presidensiil semestinya menempatkan wakil rakyat sebagai wakil politico, (Miriam Budiardjo dan Ibrahim Ambong, 1993 : 76) yang mana wakil rakyat dapat bertindak pada dua sisi, yakni yang pertama wakil rakyat sebagai wakil dengan pertimbangan sendiri, dan sebagai utusan uakni tetap memperhatikan siapa yang diwakilinya, yakni rakyat bukanlah partai politik.

\section{Kesimpulan}

Berdasarkan pembahasan di atas, maka dapat disimpulkan yakni, Pertama, terdapat resultan antara sistem pemilu terhadap pelaksanaan demokrasi di Indonesia dilihat dari teori kedulatan rakyat dan sistem perwakilan. Resultan menjadi kuat apabila sistem pemilihan umum yang dipakai adalah sistem pemilihan umum proporsional terbuka murni, yakni pemilih sebagai konstiten pemegang kedaulatan tertinggi, dapat mengetahui dengan pasti siapa calon wakil rakyat dan ikut menentukan siapa yang menjadi wakil rakyat. Kedua, terdapat resultan antara sistem pemerintahan dengan pelasanaan demokrasi, teori kedaulatan rakyat dan sistem perwakilan. Sistem pemerintahan parlementer dan presidensiil memiliki titik lemah dan kelebihan masing-masing. Namun sistem presidensiil yang diterapakn pada negara demokrasi di Indonesia lebih baik, karena cenderung lebih stabil dalam pertanggungjawabannya. Menempatkan kedaulatan tertinggi sebagai satu-satunya pihak yang menerima pertanggungjawaban orang-orang yang sudah dipilih pada lembaga eksekutif maupun parlemen. Konsep yang dibangun adalah sistem perwakilan politis, bukan sebagai sistem perwakilan partisan.

\section{Daftar Referensi}

Buku: 
Jurnal Yustika

Vol. 22 No. O2, Des 2019

Halaman | 83

Resultan Sistem Pemilu dan Sistem Pemerintahan terhadap Pelaksanaan Demokrasi di Indonesia Anajeng Estri Edhi Mahanani
Arend Liphart. (1984). Democracies, Patterns of Majoritarian and Consensus Government in Twenty-One Countries. New Haven: Yale University Press.

Dwi Sulisworo, Tri Wahyuningsih, Dikdik Baegaqi Arif. (2012). Bahan Ajar "Demokrasi", Hibah Materi Pembelajaran Non Konvensional, Yogyakarta : Universitas Ahmad Dahlan Program Studi Pendidikan Kewarganegaraan.

I Gde Pantja Astawa. (2008). Problematika Hukum Otonomi Daerah di Indonesia. Bandung : Alumni.

Mariana, D., Paskalina, C., \& Yuningsih, N. Y. (2007). Perbandingan Pemerintahan. Jakarta: Universitas Terbuka.

Miriam Budiarjo. (1985). DasarDasar Ilmu Politik [The Principles of Political Science]. Jakarta: Gramedia. dan Ibrahim Ambong (ed), 1993, Fungsi Legislatif dalam Sistem Politik Indonesia, Rajawali Press - AIPI Jakarta, Jakarta.

Sarundajang, S. H. (2012). Babak Baru Sistim Pemerintahan. Jakarta: Kata Hasta Pustaka.

Syafiie, I. K. (2011). Pengantar Ilmu Pemerintahan. Bandung: PT. Refika Aditama. \& Azikin, A. (2008). Perbandingan Pemerintahan. Bandung: PT. Refika Aditama.

\section{Artikel Jurnal:}

Aminah, 2012. Analisis Penerapan Sistem Proporsional dan Sistem Distrik dalam Pemilihan Umum untuk Penyederhanaan Sistem Kepartaian di Indonesia ditinjau dari Asas Negara Hukum, Yustisia Vol.1 No. 2, 78 .

Muliadi Anangkota. Klasifikasi SIstem Pemerintahan Perspektif Pemerintahan Modern Kekinian, Cosmogov : Jurnal Imu Pemerintahan Vol. 3 No. 2, 151-153. 